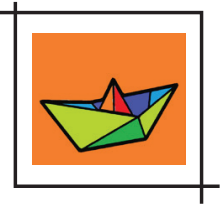

\title{
MEMÓRIA E IDENTIDADES DOS FIÉIS DA ASSEMBLEIA DE DEUS EM RELAÇÃO AO URBANO E AO CAMPO
}

\author{
Otávio Barduzzi Rodrigues da Costa*
}

\begin{abstract}
Resumo: Há inúmeras caracteristicas comuns entre o fiel da Assembleia de Deus e a herança rural no Brasil. Este artigo pretende tecer certas considerações sobre a influência dos valores rurais brasileiros na constituição da matriz cultural dos fiéis da Assembleia de Deus. Ao passar do rural para o urbano, a mensagem tinha de ser única e o visual também, era um modo de se adaptar à Modernidade. Nesse redemoinho de transformações intensas e permanentes, a religião pentecostal entra em cena como estratégia de solução e significação da passagem, determinando os limites dentro do grande espaço sem limites, restabelecendo os laços de proximidade, compondo sentidos gerais e resistindo ou negociando com o novo.
\end{abstract}

Palavras-chave: Pentecostalismo. Cultura. História da religião. Sociologia. Antropologia da religião.

\section{INTRODUÇÃO}

A história se move por um processo de contradição dialética, não por meio da ideia iluminista de progresso universal. Para Hobsbawm, o periodo entre revoluções consistia em refletir "a natureza da sociedade e a direção para a qual ela estava encaminhando ou deveria se encaminhar" (1991, p. 255). Nessa disputa teórica entre progressistas liberais e radicais, surgem diversas teorias sobre história. No século XX, há uma nova perspectiva que vige, pois a história parece tentar romper de vez com o progressismo positivista, respeitando a ordem e a cultura locais.

As ideias de Henri Lefebvre (1901-1991) (1972) resgatam, particularmente, o método de análise regressivo-progressivo, proposto pelo autor como modo de decifração dos processos ocorridos em rupturas e permanências em uma relação dialética da história. 0 método regressivo-progressivo, em forçosa sintese, está imbuído de uma metodologia dialética marxista e estabelece como emerge o presente, vendo o passado em um modo de historicização,

\footnotetext{
* Mestre em Filosofia pela Universidade Estadual Paulista "Júlio de Mesquita Filho" (Unesp). Doutorando em Educação, Arte e História da Cultura pela Universidade Presbiteriana Mackenzie (UPM), professor e coordenador do curso de Direito na Faculdade Origenes Lessa (Facol). Bolsista Prosup/Mack. E-mail: joebarduzzi@yahoo.com.br
} 
não apenas para explicar o passado, mas, sobretudo, para esclarecer os processos em curso no presente que apontam para o futuro.

A ideia de rupturas e permanências é uma perspectiva teórica de compreensão histórica do mundo. É por meio dessa compreensão que se pode conhecer e compreender narrativas a respeito das relações humanas no tempo e espaço. No cotidiano podemos notar algumas rupturas e permanências com relação a vários períodos históricos, como, por exemplo, o período medieval: antes comum, hoje já não se vê a prática de caça às bruxas ou condenação de hereges em praça pública, o que representa uma ruptura. No entanto, ainda hoje, igrejas cristãs, sobretudo pentecostais, condenam as práticas de saberes populares de outras religiões', que poderiam ser, na era medieval, confundidas com práticas de bruxaria, isto é, permanência.

A dialetização do método, proposta por Lefebvre (1983), impõe a consideração de duas dimensões temporais entrelaçadas: a dimensão horizontal ou sincrônica, que permite estudar a inserção do objeto de estudo no contexto de sua época, e a dimensão vertical ou diacrônica, que estuda a coexistência de processos históricos diferentemente datados. 0 conhecimento deve ser submetido a um "movimento de duplo sentido: regressivo (do virtual ao atual, do atual ao passado) e progressivo (do superado e do terminado, ao movimento que determina aquela conclusão e que anuncia e faz surgir algo novo)" (LEFEBVRE, 1972, p. 30). A aplicação do método regressivo-progressivo pressupõe uma abertura metodológica de entender que determinados processos culturais são plenos de imbricações entre passado e presente. Assim, a história não deveria ser vista como uma sucessão progressista de fatos ocorridos, mas como processos articulados no quadro de forças em conjunção seletiva existente no presente (SANTOS, 1999, p. 265). De acordo com Lefebvre (1983, p. 231): "evitar a confusão numa continuidade ilusória, bem como as separações ou descontinuidades absolutas, esta é a regra metodológica".

Ao estudar grupos urbanos, deve-se levar em conta que tudo veio do campo no Brasil, é reconhecer que eles carregam algo do rural, sobretudo nas periferias. A cidade surge da necessidade do encontro de vontades e objetivos comuns que permitirão a formação da cidade e daquilo que ela virá a se tornar. Lefebvre (1983), por sua vez, identificará aí o nascedouro da forma da centralidade e da simultaneidade, que caracterizará, a partir de então, a própria essência do fenômeno urbano. Contudo, carrega ainda as raízes da sociedade rural - ela ainda não desapareceu completamente -, que é a sociedade da escassez, da luta pela sobrevivência, do esforço, marcada, sobretudo, por estreita ligação com a natureza e com os deuses, pelas crenças do conhecimento popular.

Há inúmeras características comuns entre o fiel da Assembleia de Deus (AD) e a herança rural no Brasil. Este artigo pretende tecer certas considerações sobre a influência dos valores

1 - Por exemplo, há tremenda perseguição e disputa do campo religioso entre igrejas evangélicas e igrejas de matriz afro, sendo que as a primeiras acusam as segundas de bruxaria. 
rurais brasileiros na constituição da matriz cultural dos fiéis da AD. Ao passar do rural para o urbano, a mensagem tinha de ser única e o visual também, era um modo de se adaptar à Modernidade.

Vários discursos que carregam valores da permanência do passado na visão de mundo das assembleias de Deus, no entanto, agora se rompem inúmeras dessas tradições formadas em prol da busca por um projeto de poder, de readequações e novidades expressas pelo consumo de bens culturais e vivência na cidade. Sua crença, no sentido em que nos fala Certeau (2008), não está mais apenas em uma entidade invisivel, mas em estruturações sociais visíveis. Assim, crenças direcionam não mais um mundo espiritual, mas um mundo real, onde não haverá diferença entre tais mundos.

A crença não repousa mais em uma alteridade invisivel, escondida por trás dos signos, mas em cima daquilo que outros grupos, outros campos, ou outras disciplinas supostamente são. 0 "real" é aquilo que, em cada lugar, a referência, a um outro acreditar (CERTEAU, 2008, p. 289).

A crença muda e cede espaço a novas formas de fazer e crer. Certeau chega a afirmar que as igrejas estão passando por uma ruptura da crença, o que era só algo espiritual, agora passa por um processo de racionalização, semelhante aos partidos políticos e empresas.

Esta analogia tem razões estruturais, elas não remetem diretamente a uma psicologia da militância ou a uma sociologia crítica das ideologias, mas antes de tudo à lógica de um "lugar" que produz e reproduz, como seus efeitos, as mobilizações militantes, as táticas do "fazer crer" e das instituições eclesiais em uma relação de distância, de competição e de transformação futura em relação aos poderes estabelecidos (CERTEAU, 2008, p. 285).

Nesse redemoinho de transformações intensas e permanentes, a religião pentecostal entra em cena como estratégia de solução e (re)significação da passagem do rural para o urbano, determinando os limites dentro do grande espaço sem limites, restabelecendo os laços de proximidade, compondo sentidos gerais e resistindo ou negociando com o novo. As massas rurais que migraram para as periferias urbanas passaram por crises em suas compreensões de mundo, formas de sobrevivência, quebra dos sonhos e os abalos emocionais deixaram (e deixam) os indivíduos anônimos em busca de estabilidade referencial. As balizas simbólicas das origens interioranas não mais respondem à nova situação emergente da metrópole caótica. As crenças e os significados trazidos em seu imaginário não transmitem referenciais condizentes aos riscos de identidade e sobrevivência do indivíduo e da coletividade.

A comunidade crê que as regras da igreja provém de um ser sagrado nos moldes Eliadeanos, donde a comunidade é santa e o mundo é pecaminoso. Os costumes da igreja são puros e a realidade circundante é impura. Além disso, cada vez mais a comunidade, em especial a 
juventude, passa por absorções desse novo tempo e espaço, ao passo que a igreja se encarrega dessas novas formas de comunicação e adaptações, ora mantendo modos de ser e fazer antigos, ora rompendo, gerando sucessivas descontinuidades e rupturas.

É nessa erosão humana, em território estranho, que o individuo que trouxe uma bagagem de crença vai recorrer ao socorro das forças sobrenaturais na esperança de obter alternativas ao caos amedrontador. Na instabilidade humana e social, o perfil cristão diferenciado da igreja pentecostal, com sua agregação solidária, será a âncora perante a avalanche de quebra de referenciais à existência do indivíduo. São essas mudanças que se pretende apontar.

\section{O CONTEMPORÂNEO NO PASSADO}

A contemporaneidade, caracterizada pelo mercado financeiro fetichista da mercadoria (MARCUSE, 1973), informações e globalização capitalista, torna acessível uma diversidade cultural líquida aos sujeitos, o que rompe antigos referenciais de vida e cria incertezas a respeito do significado das coisas.

Apesar de haver pentecostalismos, o assembleiano a que me refiro aqui é um tipo em extinção, seria a construção de um tipo ideal weberiano. É aquele que se afasta do mundo, no seu ascetismo intramundano, não o que tem se aproximado do mundo a largos passos. A imagem de senso comum - o crente de terno e gravata em pleno calor do Rio de Janeiro, com a Bíblia debaixo do braço, ou a irmã de saias e cabelos compridos - ainda existe, porém isso tem mudado. Primeiramente, tal identidade significava existir fora do mundo moderno, sem vaidade, sem participar do capitalismo, sem televisão, sem participar de esportes, em um semi-isolamento psicoespiritual. Essa identidade tem relação com uma memória histórica que se encontra em plena extinção, mas é a esse tipo de ideal que nos referimos neste trabalho, o que também será denominado aqui pentecostalismo tradicional.

Nosso tipo ideal ainda existe, porém, ao lado dele, dentro das assembleias de Deus (ADs), também está o jovem com dreads no cabelo, a mulher de cabelo curto, a jovem toda tatuada e com piercings. Todos adorando a Deus, erguendo os braços, falando expressões como "glória a Deus", emocionando-se, orando uns pelos outros, profetizando, falando em línguas estranhas, chorando, rindo e cantando ao som do mesmo louvor.

Hoje em dia se fala em pentecostalismos e assembleianismos, no plural. Em especial, a pesquisa de Alencar $(2013$, p. 2), que afirma suas "identidades irreversivelmente fracionadas em divergências internas", gerando os assembleianismos urbano, rural, difuso e autônomo, clássico. Na introdução de seu livro, o autor deixa claro que: "Não se trata, assim, de uma igreja, mas de diversas, distintas, concorrentes e divergentes entre si, muito parecidas com o pais onde nasceram, cresceram e se consolidaram. Portanto, Assembleias Brasileiras de Deus" (ALENCAR, 2013, p. 3). 
Assim, assume uma configuração própria da cultura do Brasil que é mutante e diversa, difícil de compreender (RIBEIRO, 1996). Marcada pela pluralidade e complexidade, a história pentecostal brasileira nunca apresentou uma só matriz histórica. Mesmo sendo uma igreja fundada por suecos, havia uma liberdade que encantava o brasileiro, como aponta Santos (2013, p. 79): torna-se uma igreja sueca com "jeitinho brasileiro".

\title{
MEMÓRIA E IDENTIDADE
}

A identidade do fiel assembleiano se encontra entre fronteiras culturais do conservacionismo ascético intramundano e da sedução pela mercadoria ou rompimento do tradicionalismo em identidades aparentemente contraditórias - uma construção de uma identidade complexa.

A construção da identidade, sobretudo da religiosa, não mais encontra padrões uniformes na pós-modernidade, que é marcada pela falência das metanarrativas. Cada sujeito dará sentido à sua identidade conforme o sentimento de pertencimento que mantém, porém, essa relação fica complicada em meio a uma instituição que prega valores comportamentais mais ou menos padronizados. Vale também concordar com Cabral e Lourenço (1993, p. 162), que, num estudo em Macau, território de intensa circulação de grupos de diferentes origens, observaram que "Perante situações muito semelhantes, as opções identitárias de cada pessoa podem ser radicalmente diferentes". Para esses autores, isso ocorre porque as pessoas optam por "[...] posicionamentos distintos por razões que só o seu passado pessoal e psicológico poderá determinar". Sendo uma igreja assembleiana brasileira um território também de grande afluxo cultural, e que assumiu ao longo de sua história valores suecos e norte-americanos, entre outros, institucionais, vale o trabalho dos pesquisadores macauenses.

Analisando essa questão, define Pesavento (2002, p. 36):

\begin{abstract}
[...] fronteiras culturais remetem à vivência, às sociedades, às formas de pensar intercambiáveis, aos ethos, valores, significados contidos nas coisas, palavras, gestos, ritos, comportamentos e ideias. [...], a fronteira cultural aponta para a forma pela qual os homens investem no mundo, conferindo sentidos de reconhecimento. A fronteira cultural é trânsito e passagem, que ultrapassa os próprios limites que fixa, ela proporciona o surgimento de algo novo e diferente, possibilitado pela situação exemplar do contato, da mistura, da troca, do hibridismo, da mestiçagem cultural.
\end{abstract}

As autoidentificações culturais são partes de um processo caótico e complexo, tanto na forma quanto no conteúdo. Dentro do grupo, os membros ocultam e negociam as significações identitárias de seus bens simbólicos, conforme a teoria bourdiana, de modo que se situem 
como melhor Ihes convier nas relações. Desde Barth, sabe-se que as fronteiras culturais podem se tornar permeáveis ou desaparecer, levando à fusão de culturas previamente separadas.

Ao ser admitido (convertido) em um grupo, o novo membro começa a utilizar uma nova linguagem para referenciar o mundo. Exorcismo e libertação, cura e salvação, prosperidade e sucesso são três aspectos indissolúveis da visão teológica dos líderes das igrejas estudadas, que, de uma maneira bem prática, procuram apresentar ao fiel mais do que uma visão de mundo, mas um "guia para a ação sobre o mundo" (WILLAIME, 1992, p. 62, tradução nossa).

A cultura e, portanto, a identidade assembleiana está separada por valores anacrônicos em meio à urbanidade pós-moderna, porém aos poucos muda e adapta-se, aceitando valores e estéticas dessa urbanidade. Esse movimento pode fazer emergir novas fronteiras culturais ou ocasionar a mudança de lugar das velhas fronteiras, possibilitando o surgimento de novas formas de adaptação religiosa ou a reformulação das antigas.

Assim, o jovem pentecostal está entre a aceitação e a negação das coisas modernas e urbanas, a aceitação e a negação do rap, entre negação e aceitação da vida noturna e das estruturas complexas que perfazem a juventude. Ele está entre a liberdade e a repressão pela igreja, podendo ou não aceitar as práticas contemporâneas.

Ser um jovem pentecostal é, ao mesmo tempo, ter que se comportar e dançar rap, libertando seu corpo e aceitando novas formas urbanas.

Além disso, esses fenômenos oferecem explicações míticas e místicas aos membros da igreja que tentam justificar certas realidades e a nova compreensão que o sujeito tem sobre um mundo invisivel, ainda que esse mundo pareça ter mais influência sobre ele do que o mundo sensivel que o cerca.

Assim, desde um ponto de vista antropológico, é possivel reconhecer que as crenças são atravessadas pela cultura em diferentes épocas e sociedades. Com efeito, os significados culturais marcam tanto a pessoa doente, imprimindo-Ihe sentidos existenciais, quanto os seus líderes, particularmente os pastores, no papel de sábios ou curandeiros (BASTIDE, 2006), os quais constituem sua prática com base em redes semânticas culturais centradas na dimensão ritual. Na perspectiva dos crentes, os significados culturais subscrevem os sentidos existenciais das pessoas e "estão inscritos na fala através de idiomas e metáforas culturalmente determinados que articulam a experiência religiosa e consequentemente espiritual" (DESROCHE, 1985, p. 62).

Com efeito, é na comunicação verbal que podemos reconhecer um discurso que pode ser tratado no jogo de sua instância, que se caracteriza não por uma continuidade, mas por rupturas e descontinuidades, sendo, então, possivel considerar a existência de múltiplas formações discursivas referentes ao corpo e seu senso estético, que tomam corpo nas narrativas sobre a crença. Essas formações discursivas, por seu turno, correspondem à experiência da crença, por meio da qual se constituem os sentidos a elas referentes. A pessoa pensa que seus atos sociais (pecados ou provas) causaram certo castigo, isso modifica seu contato 
social e ela sai em busca de purificação, mudando sua relação com o mundo ou discursando mudá-la. Essa purificação é demonstrada por meio do corpo e da vestimenta.

No caso em estudo, a memória e a identidade pentecostal, a linguagem tem grande importância e a pessoa passa a se identificar por uma série de linguagens próprias, que se expressam tanto no vocabulário quanto, com mais impacto, no próprio modo de vida do fiel. Ao assumir os modos do grupo, seus costumes e práticas, a mudança de pensamento pode chegar à autonegação de si, ou melhor, do seu passado. 0 novo convertido assume uma identidade diferente. Tal fenômeno não aparece só na religião, mas em todo grupo em que haja um interesse ou necessidade de justificar os seus atos presentes ou seus costumes e crenças (BECK; FREEMAN, 1993).

A linguagem humana é um sistema que faz a consciência emergir dinamicamente, uma nova ordem de refletividade em que o sujeito se vê e se reconhece por meio da mente, ou seja, a linguagem é o meio pelo qual o sujeito referencia a si e ao mundo (BODEN, 2004, p. 158). A participação em um grupo social religioso muda a forma como o ser humano se relaciona com o mundo, proporciona uma nova visão e traz novas explicações ao ser convertido.

\section{A IDENTIDADE PENTECOSTAL}

Numa perspectiva religiosa, a memória, entre seus inúmeros aspectos, pode ser vista como tradição. Segundo Rivera (2002), a transmissão da tradição visa a manter intacta a lembrança dos seus fatos fundadores. Entretanto, para o pentecostal, a memória dos fatos fundadores não é tão importante quanto o texto sagrado e esse aparenta ser menos importante do que a experiência subjetiva. É essa que realmente importa e que perfaz sua identidade. Só se passa a ser pentecostal quando se tem uma experiência subjetiva com o que acredita ser o Espírito Santo, manifestado obviamente pelos dons espirituais descritos na Bíblia. Nesse campo, ocorre uma preocupação em se formar a identidade, perpetuar uma memória não histórica que se manifestará nos seus códigos de conduta, costumes e vestimenta, bem como sua linguagem. Em suma, existe uma transmissão de memória ativa que constitui uma identidade diferenciada desconexa da memória oficial, positivista e histórica.

A memória pode ser encarada não somente como uma ferramenta de guardar dados mnemônicos, mas, sobretudo, como uma capacidade de (re)significação das coisas e de si mesmo (RICOEUR, 2007, p. 40). Ela se manifesta em uma crença coerente com um comportamento social que constitui a sua identidade diferenciada de qualquer outro grupo. Essa identidade faz-se transmissivel não exatamente por meio de um discurso ou de uma recuperação de memória, mas, sim, de uma imitação desconexa da história formal, feita por outros membros mais antigos do grupo, que se manifesta coletivamente. 0 convertido pentecostal não chega de terno e gravada citando trechos da Bíblia, ao contrário, muitas vezes sua natureza anterior era diametralmente o contrário da figura assembleiana: liberais em relação a 
assuntos sexuais; pessoas que consumiam bebidas alcoólicas em excesso; pessoas sem qualquer conhecimento bíblico. Por convivência e imitação, adquire os hábitos, as práticas cotidianas, a linguagem, os costumes daquele grupo, assumindo assim uma disposição bourdiana de habitus daquele grupo. Aqui entende-se habitus como:

\section{[...] um sistema de disposições duráveis e transponiveis que, integrando todas as experiên- cias passadas, funciona a cada momento como uma matriz de percepções, de apreciações e de ações - e torna possivel a realização de tarefas infinitamente diferenciadas, graças às transferências analógicas de esquemas [...] (BOURDIEU, 1987, p. 65).}

Ao ser convertido, o fiel cria e recria modos de ser, fazer e relacionar-se, ou seja, disposições do ser, que serão mais ou menos duráveis, transpondo-se a outras práticas que transcenderão as religiosas e serão de toda a vida, adquiridas com as experiências dos membros que já pertenciam ao grupo. Cria-se, assim, uma matriz de ver, apreciar (instituir valor) e agir no mundo. Desse modo, realiza sua vida de acordo com os novos valores que lhe foram transmitidos.

Conceituar experiência religiosa não é coisa fácil. Há inúmeros conceitos, mas é a partir da experiência que o sujeito identifica-se como verdadeiramente pentecostal. Mas não é só com a experiência, é um misto de conversão e aceitação da comunidade e da experiência. Só a partir desse fenômeno ele será aceito em sua comunidade e poderá ser considerado um santo de Deus. Os assembleianos acreditam literalmente no relatado na Bíblia em João 3:5 (novo batismo). É somente ao ser batizado com o Espírito ou ter uma experiência religiosa que ele será considerado fiel e sua comunidade o aceitará como verdadeiro filho de Deus, não é só por frequentar os cultos, passar por batismo nas águas e assumir a sua linguagem. Além de todas essas etapas, para se tornar um verdadeiro pertencente da comunidade, ele ainda tem de passar pela experiência religiosa espiritual.

Segundo Otto (2007), o sagrado é aquilo que dá sentido à vida das pessoas. Mas o que é, afinal, esse sagrado? 0 que é e como é esse que foge de toda e qualquer racionalidade? E assim considera o sagrado um mistério tremendo. Conceitualmente, mistério designa nada mais que o oculto, ou seja, o não evidente, não apreendido, não entendido, não cotidiano, nem familiar, sem designá-lo mais precisamente segundo seu atributo. Contudo, o sentido intencionado é algo positivo por excelência. Seu aspecto positivo é experimentado exclusivamente em sentimentos.

Podemos explicitar esses sentimentos em formulações sugestivas. [...] 0 atributo tremendum é, para começar, uma caracterização positiva do que estamos tratando. 0 termo latino tremor significa apenas medo ou temor - sentimento "natural" bastante conhecido" (OTTO, 2007, p. 45). Em algumas linguas, existem expressões que designam exclusiva e preponderantemente esse temor, que é mais que temor. Por exemplo, hiqdish, que significa santificar em hebraico. Santificar algo em seu coração significa distingui-lo por sentimento de receio 
peculiar, que não deve ser confundido com outros receios. Significa valorizá-lo pela categoria do numinoso (0TTO, 2007).

Rubem Alves (1988, p. 33) afirma que ao declarar-se religioso, o homem se define:

A religião é o ato pelo qual o ser humano se separa de si mesmo e no qual contempla a sua natureza latente. Deus é o símbolo para a resposta à pergunta: Quem sou? 0 que o ser humano declara acerca de Deus ele, na realidade, afirma acerca de si mesmo.

Brandão (1992, p. 39-40) afirma que o pentecostal ressignifica todos os aspectos da sua vida de um modo impactante ao referir a si mesmo como tal:

Para o sujeito que se autonominará "pentecostal", "pentecostista" (mais raro), "pentecoste", "crente" (o mais comum), "evangélico" (que inclui os protestantes não-pentecostais), "um crente no Senhor Jesus", ". . . da Assembléia de Deus", o ser crente obriga o sujeito a uma ativa enunciação de sua pessoa social através da sua identidade religiosa. Mais asperamente visivel hoje em dia entre os pentecostais do que entre todos os outros sujeitos evangélicos e vizinhos próximos de fé, ao declarar-se um pentecostal modifica toda a autoimagem do enunciador, subordinando-a ao qualificador religioso, sobretudo quando ele se reconhece um convertido, logo, um sujeito salvo desde o momento e por causa do ato de conversão pessoal, mais do que apenas por possuir uma religião. Em seguida a enunciação do seu ser religioso requalifica todos os outros atributos de sua identidade social e/ou étnica, em função de uma assumida qualidade de ser-pessoa-através-da-religião, sob cujos efeitos todos os outros nomes, títulos, condições de classe e posições sociais e culturais são revistos e hierarquicamente reordenados. Convertido em um agora leitor assíduo de um único livro, a Bíblia, o sujeito crente se re-escreve, de acordo com a leitura pessoal que faz dela e segundo a figura de "homem novo" que desenha para si mesmo, através da maneira como aprende a pensar e ser em sua comunidade de fé e de restrita e exclusiva salvação. No Brasil um homem adulto, negro, pobre e lavrador, torcedor do Cruzeiro Futebol Clube, de Minas Gerais, com o sobrenome Bento Teixeira, depois de convertido a uma Assembleia de Deus passará a proclamar-se um "crente, salvo no Senhor", um homem pobre e negro, mas honrado, Bento Teixeira (mas sem dar ao "ser do povo dos Bento Teixeira" importância alguma, porquanto a sua familia agora é a comunidade de sua igreja) e desinteressado tanto do Cruzeiro como do futebol e de tudo o mais que, a partir de um "momento de salvação", ele traça e delineia como parte das "coisas do mundo", que evita ativamente.

Assim o pentecostal reafirma-se como pertencente a algo maior do que ele e essa experiência determinará toda a sua vida. A experiência é um misto do que ele crê ser sagrado e de ser aceito no seu grupo. Sobre isso escreve Rolim (1985, p. 225): 
Os crentes produzem um imaginário sob cuja influência experimentam simultaneamente o aspecto de proteção e de existência do grupo. Proteção porquê de um lado a crença no Espírito Santo é a crença no poder divino absoluto, e, por outro lado, o grupo é percebido como espaço por excelência da manifestação desse poder, o qual se reproduz e re-atualiza a manifestação primitiva desse mesmo Espírito.

É por meio da experiência que o crente é reconhecido e cria sua identidade de sujeito coletivo. Ao reelaborar uma linguagem nova, a partir daquilo que já the era comum em sua religiosidade e com o acréscimo do discurso bíblico, o convertido estrutura uma nova realidade e um novo imaginário que definem uma nova maneira de viver e de relacionar-se socialmente. Cria, portanto, novas relações de força e de poder diante das dificuldades do cotidiano (COSTA, 2006).

Sua experiência consiste na crença do enconto com o Espírito Santo e isso determina toda a sua vida, inclusive extrarreligiosa, algo que não acontecia há séculos na cristandade. Desde o início da Modernidade, a vida cristã se divide em duas, uma nos cultos e outra na vida cotidiana. É evidente que uma influencia a outra, porém, para o pentecostal, ao contrário do que fundamentam os pensadores modernos acerca de religião, vive-se apenas no sagrado. 0 "sagrado" existe, segundo Eliade (2001), em oposição ao profano. Ele se constitui na concepção de um mundo transumano, comumente de origem divina, que diz respeito à existência de uma transcendência que extrapola os quadros da realidade imediatamente visivel e sensivel. Porém, o assembleiano constitui-se no sagrado. Crê que tudo em sua vida é sagrado, sua família, seu trabalho, suas manifestações religiosas, suas palavras, sua moral, seu modo de se relacionar com os outros, em suma, acredita que sua vida é sagrada.

0 profano manifesta-se naquilo que é pecado e sua vida se torna uma busca de separação do que seja pecado. Isso não significa que ele não peque, mas, ao menos em seu discurso social, busca viver a santidade. Aliás, é o primeiro a assumir que todos são pecadores, mas sua vida se transforma a partir dessa experiência. Contudo, mesmo o profano é espiritual ou sagrado no sentido eliadiano, pois acredita-se que se trata de uma força espiritual (maligna), o diabo, que faz que as pessoas pequem.

A experiência espiritual é inexplicável racionalmente. Os relatos são de puro transe, ou seja, não dá para o sujeito que sofreu a experiência explicar, ao menos em nível consciente, mas a partir dessa experiência relata que sua vida muda. Há diversos relatos de pessoas que mudam radicalmente de vida após a experiência, os exemplos são inúmeros: prostitutas que controlam sua sexualidade, bandidos que não roubam mais. A experiência chega a ser superior à dependência neuroquímica: há diversos relatos de pessoas que pararam de usar drogas, bebidas e cigarro após serem "batizadas" com o Espírito Santo, talvez porque seja outra experiência neuroquímica. A mudança se expressa nas roupas típicas, na forma de agir e na assunção de uma nova linguagem. Basta conversar poucos minutos com um pentecostal 
para que perceba que ele é pentecostal, ainda que suas roupas não denunciem - se estivesse vestindo uniforme de trabalho, por exemplo. Mesmo em meio urbano pode-se, nos metrôs da periferia, ver senhoras e senhores de vestido típico da Assembleia de Deus, de forte influência rural, pregando a palavra de Deus aos ouvidos surdos da cidade.

Émile Durkheim (1996, p. 51), estudando a religião, observa que "o sagrado e o profano foram pensados pelo espírito humano como gêneros distintos, como dois mundos que não têm nada em comum". E conclui: "existe religião tão logo o sagrado se distingue do profano" (DURKHEIM, 1996, p. 150). Nesse sentido, considera-se sagrado tudo aquilo que está ligado à religião, à magia, aos mitos e às crenças. Em qualquer religião, a concepção do sagrado manifesta-se sempre como uma realidade diferente da natural, remetendo ao extraordinário, ao anormal, ao transcendental, ao metafísico. Quando o processo é tratado como um fato natural, biológico, normal, estamos no campo do profano, de tudo aquilo que não é sagrado. Entretanto, para o pentecostal, tudo é sagrado, mesmo o mundo profano, pois é algo espiritual, o diabo, que o impulsiona.

\title{
OUTROS RUMOS DA IDENTIDADE PENTECOSTAL
}

A identidade do homem pentecostal é levada para outros âmbitos da vida além da religiosa. Nunca é somente em suas práticas litúrgicas que se refere como santo ou crente, com todas as implicações que essa identidade traz. Ser pentecostal é criar e passar uma imagem em sociedade de um ser que se porta de acordo com suas crenças. Isso não é novo nem único na história. De fato, ele acredita que todos os passos da sua vida são controlados por forças divinas, não há papel social por meio de hipocrisia (ao menos na maioria desses fiéis). Todos os seus papéis sociais, que desenvolve no trabalho, na família, na igreja, nas diversões, na vestimenta e até na alimentação ${ }^{2}$, são resultado da representação do fiel.

\begin{abstract}
Uma identidade pentecostal é, mais do que a protestante histórica e muito mais do que a católica (fora os casos de pessoas e grupos de militância católica), a afirmação de um modo de ser dominado pela religião. Uma pessoa "crente" é, antes de tudo, a pessoa de um crente, e todos os outros qualificadores de sua identidade - o local de origem no país, o grau de instrução escolar, a profissão atual, a definição política - são secundários, ou são reescritos, a partir da maneira como o sujeito pentecostal submete todas as dimensões de sua ação social e representação que faz de si, através de tal ação significativa, aos termos e símbolos de sua identidade militantemente religiosa (BRANDÃO, 1986, p. 36).
\end{abstract}

\footnotetext{
2 - Não consomem bebidas alcoólicas e nem produtos que acreditam no que está escrito em Corintios 10:21: "Não podeis beber o cálice do Senhor e o cálice dos demônios; não podeis ser participantes da mesa do Senhor e da mesa dos demônios" e "não vos embriagueis com vinho, em que há contenda, mas enchei-vos do Espírito" escrito em Efésios 5:18.
} 
Ao falar de identidade, afastamo-nos da sua característica social e nos concentramos na individual, porém o indivíduo é constituído socioculturalmente. Apesar de não sermos exclusivamente culturais, não somos apenas individuos biológicos. Lévi-Strauss (PAZ, 1977, p. 102) critica a definição de identidade, afirmando que: "[...] a identidade não corresponderia a nenhuma experiência substantiva, mas seria um foco virtual, um esforço de construção indispensável à explicação, mas cuja existência seria puramente teórica". Assim, as identidades não resultam espontaneamente do pertencimento empírico a uma cultura, há uma relação entre memória, indivíduo e a cultura à qual pertence, que constitui o seu ser, a sua identidade, o que ele é em essência.

Os pentecostais assembleianos do Brasil não possuem, como os católicos ou batistas, uma instituição coesa que Ihes representa - visto que a Convenção Geral da Assembleia de Deus no Brasil (CGDAB) pouco representa o fiel ou mesmo os pastores -; tampouco possuem uma homogeneidade doutrinária, litúrgica ou mesmo de costumes e tradições capaz de ser utilizada como senha única de identidade. Como já dito, os poucos códigos de conduta que thes representavam estão em profunda mutação (MARIANO, 1999).

0 assembleiano se forma na comunidade. Se isolado, não mantém muito tempo a noção de conversão de seu ethos de sua adquirida identidade, pois não teria o seu espelho, seu irmão em fé, de quem absorve novos jeitos de ser falar e referenciar o mundo, que the dá o significado de sua própria existência. A formação identitária pentecostal somente se realiza na sua comunidade com seus irmãos, isto é, a criação de uma identidade que perfaz uma memória halbachiana, ou seja, independente de memória formal, porém rica e multicultural, uma identidade pouco coesa, mas, por isso mesmo, interessante (ou com riscos políticos, no caso da absorção da teologia da prosperidade).

Sua memória é perpassada por uma linguagem definida como o meio pelo qual o grupo, ou individuo, se refere a si mesmo e ao mundo e assume-se diferente em um processo de conversão, porém ele tem se tornado mais líquido nesses últimos tempos. Isso não significa somente a quebra de uma identidade e de rompimento de transmissão de memória de um novo grupo que se reconfigura.

\section{DO RURAL PARA O URBANO}

0 meio rural em crise dá lugar à migração urbana, que, por sua vez, dá novo significado a todos que vivem nesse ambiente. 0 pentecostal é afetado sui generis nessa mudança. A crise do meio rural é bem apontada por Martins (2008) nesse Brasil que aceita uma desordenada, tardia e repentina modernização, que culmina em uma igualmente desordenada urbanização.

A padronização de vestimenta foi um meio de se igualar aos irmãos, diferenciando-se do mundo ao entorno em um período de institucionalização da igreja (ALENCAR, 2013) e a 
padronização, se vestir parecido, seria importante. Era um jeito estético de ser igual aos irmãos e diferente do mundo ao entorno.

As similaridades assembleianas com a cultura e a moral rurais são expressivas. No meio rural, não há liberdade sexual - as relações são monogâmicas, não se aceita experiência sexual antes do casamento; moça honrada vai para o leito nupcial virgem. Ainda, no meio rural, a pessoa que bebe não trabalha direito no dia seguinte, ficando difamada, pois não contribui com o grupo. No pentecostalismo, chega a ser proibido o consumo de álcool. As vestimentas de uma mulher devem ser compridas para não mostrar o corpo, as de um homem de bem, em público, são terno e gravata. A sensualidade é malvista. Assim, esses valores são trazidos ao grupo e há uma divisão entre seres do bem e seres mundanos.

Na comunidade rural, o que Darcy Ribeiro (1996) chama de Brasil caipira, existem laços de solidariedade e irmandade que afetam e caracterizam profundamente o meio de ser pentecostal. Essa expressão se manifesta numa rede de amizade e, ao mesmo tempo, de controle sobre a vida de cada membro da comunidade de bairro rural. Assim, é herdada ao Brasil pentecostal a noção de irmandade e de controle sobre o outro. Essa noção de controle permeia a vida do pentecostal de modo negativo. Qualquer um que sair do ideal de santidade pode sofrer consequências. Embora o discurso cristão seja de perdão dos pecados, o meio pentecostal pode excluir da comunidade aquele que transgredir seus rígidos valores morais.

Esses valores são transmitidos como referenciais do que é ser bom ou ser mau, do que é ser salvo ou não, e são evocados por meio da história com exemplos antigos de valor moral. Ao vir para a cidade, a sedução de rompimento com esses valores se demonstrou sedutora especialmente aos jovens. No entanto, agora já havia uma instituição para melhor controle dessa moral, daí, talvez, o rígido controle sobre os membros, típico da segunda fase assembleiana, que é tão acentuada, como aponta Alencar (2013).

Ao ingressar no meio urbano, os assembleianos mudaram radicalmente seu modo de ser e fazer, isso porque a mudança social no urbano acontece com toda a sociedade. A segunda fase assembleiana, carregada de institucionalização e controle dos membros, talvez seja uma tentativa paternalista, no sentido mais autoritário e machista, de tentativa e preservação da própria identidade.

0 assembleiano muitas vezes é acusado de retrógrado, mas estava imerso em uma irmandade coletiva, muito mais influente que a própria instituição assembleiana, em meio a uma mudança radical que o meio urbano apresenta ao modo de vida antes rural.

Martins (2008) se refere à dificuldade de adaptação do trabalhador rural que vem para o meio urbano, convivendo com outros modos de ser e fazer e com as rupturas com sua história. Quando esse é inserido em uma sociedade que o coloca como agente da transformação urbana, para se adaptar a esse meio, acaba teatralizando seu jeito de existir. Suas antigas práticas acabam preservando uma resistência, uma preservação de valores que consideram 
antigos e santos. Esse trabalhador, imerso em um outro modo de vida, recicla-o, reafirma e procura viver segundo as antigas relações sociais. De acordo com Martins (2008, p. 14):

reapropia-se das tradições de suas origens pré-modernas para enfrentar a privação de história e de compreensão plena que Ihe impõe a modernidade que o minimiza e coisifica. Adere, resistindo, para viver e vencer a seu modo o mal-estar da sociedade da incerteza.

Assim, passa a ressignificar tudo, a não aceitar tudo de modo dado e, dessa forma, começa a nascer o germe que culmina nas diversas e complexas mudanças e configurações pentecostais e assembleianas, na sua chegada à cidade. Isso constitui os modos de ser e fazer das ADs brasileiras.

\section{EXPANSÃO}

Nasce uma igreja com a pretensão de ser desinstitucionalizada, visto que nenhuma igreja enviou os missionários-fundadores. Eles apenas acreditavam nas palavras que ouviram em Azusa Street. Assim, a igreja nasceu por influência de Seymour, que foi um afrodescendente pobre e iletrado, cuja afinidade com instituições não era das melhores. Provavelmente sua condição social fez que as igrejas pentecostais oriundas do avivamento que surgiu em Azusa não fossem muito adeptas de forte institucionalização, prevalecendo sobre os crentes a experiência pessoal em detrimento da instituição.

Sendo uma consequência e uma reação à Modernidade, o pentecostalismo, assim como outras identidades culturais, não é rígido, e sim fluido. Há sempre uma busca pelos processos de identificação. Mesmo as identidades aparentemente mais sólidas, como a de mulher, de homem, de país africano, de país latino-americano ou de país europeu escondem negociações de sentido, jogos de polissemia, choques de temporalidades em constante processo de transformação, responsáveis, em última instância, pela sucessão de diversas configurações (SANTOS, 1997).

As identidades religiosas não fogem a essa regra, apesar de certas lideranças tentarem imprimir uma identidade única ao grupo. Na Modernidade a subjetividade sempre surge, ela pode ser entendida como a capacidade de síntese que o ser humano faz com o seu meio. Santos (1997) afirma que o primeiro nome moderno da identidade é a subjetividade.

Assim, a história do pentecostalismo e das ADs é plena de gostos pessoais, disputas e a igreja não apresenta uma identidade única, por isso também há tantas divisões em ministérios. Muito mais que a disputa política de poder, a subjetividade de indivíduos e pequenos grupos é responsável pela capacidade de divisão das ADs e de assumir novas configurações.

Em sua história, por vezes, uma liderança carismática pode ter tentado atrasar ou conter esse processo, mas a AD já nasce plural e rompendo institucionalizações. Rompeu sendo 
uma igreja de negros, rompeu com uma herança batista no Brasil, rompeu com a tradição dominante religiosa, rompeu em diversos ministérios, continua rompendo em variadas formas. É o gosto, a preferência, as partes de identidades de grupos e indivíduos que perfazem sua história recortada e complexa, e não uma instituição.

As diversas tentativas de institucionalizar não deram certo. Primeiro a Igreja Filadélfia de Estocolmo tenta englobar a Assembleia de Deus, pois se sentia compromissada ao enviar ajuda para os missionários pioneiros. Depois, a assembleia norte-americana, o que foi rejeitado pela liderança brasileira. Cria-se uma igreja única e diferente. Essa pretensa desinstitucionalização foi fundamental para a constituição da atual identidade assembleiana.

Assim, uma igreja democraticamente inédita logo haveria de ter aceitação e crescer. A leitura era estimulada e ensinada, ainda que sem muita qualidade nas igrejas. Mais tarde, na segunda fase de institucionalização, também foi a maior escola livre e gratuita de música do Brasil ${ }^{3}$.

A mensagem assembleiana também oferecia algo que as igrejas históricas protestantes e católicas não faziam: uma oportunidade ao homem pobre iletrado e simples de uma fuga dos sofrimentos desse mundo. Enquanto a mensagem católica pregava a conformação aos sofrimentos, e a protestante pregava a salvação, a pentecostal ia além, valorizava uma pessoa pobre e iletrada ter contato direto com Deus, por meio do Espírito Santo.

Alguns fatores foram importantes para o crescimento da mensagem assembleiana. 0 primeiro deles foi a crise do Ciclo da Borracha. Tendo perdido o monopólio da produção mundial de borracha, várias pessoas migraram de um lugar ao outro no Brasil em busca de novas oportunidades, muitas delas já portadoras da mensagem assembleiana.

Outro fator importante foi o crescimento da indústria ferroviária, que possibilitava o espraiamento da mensagem. Com a inauguração da Estrada de Ferro Madeira-Mamoré, várias pessoas adeptas do pentecostalismo puderam pregar essa nova forma de religião. Conhecida como ferrovia da morte (morreram cerca de 6 mil trabalhadores), a própria construção da ferrovia era um campo a ser explorado. Sem religião em meio a um campo distante, com trabalhadores iletrados, vários deles eram pentecostais e aproveitaram a falta de religiosidade e a dificil condição da construção de ferrovia para oferecer conforto espiritual às massas de trabalhadores.

Apesar da crise da borracha, a própria construção de ferrovias passou a ser lucrativa e tremendamente incentivada no Brasil por diversas companhias britânicas, norte-americanas e até brasileiras (Mauá). Tal fator é apontado como importante por Martins (2008) para integração do território nacional e, nesses trens, embarcaram vários pentecostais.

\footnotetext{
3 - Na edição de 6 de junho de 2011, a revista Veja fala da importância da música entre os evangélicos, e que eles se tornaram os novos celeiros de música erudita no Brasil. Inclusive relata na reportagem que o atual maestro da Osesp é membro da AD. Disponivel em: http://veja.abril.com.br/060607/p_104.shtml. Acesso em: 21 ago. 2014.
} 
Além disso, há o episódio da Batalha da Borracha (PRADO JR., 2004). 0 governo de Getúlio Vargas, visando aos lucros de um acordo comercial com os Estados Unidos, que precisava da borracha para sua crescente indústria bélica após a Primeira Guerra Mundial, precisa produzir borracha a qualquer custo. Com isso, emprega compulsoriamente mais de 100 mil trabalhadores, entre nordestinos e moradores do Centro-Oeste, que, expostos às piores condições de trabalho e com pouca assistência religiosa em uma condição de sofrimento e privação, encontram na mensagem pentecostal uma esperança para as agruras da vida. Ao terminar o segundo ciclo da borracha, esses trabalhadores voltam para o Nordeste e Centro-Oeste, muitos deles já portadores da mensagem assembleiana.

Com a construção de ferrovias, o Brasil é interligado em pleno auge do Ciclo do Café, que reimpulsiona a economia (MARTINS, 2008). Assim, a mensagem pode chegar de norte a sul do país. A economia do café traz vários emigrantes também (PRADO JR., 2004), que encontram aqui conterrâneos portadores da mensagem assembleiana. Com a construção de estradas de ferro e a crise do café, os pobres trabalhadores rurais, muitos deles pentecostais, chegam às cidades e aos subúrbios (MARTINS, 2008). Já estava a "pleno vapor" - mais do que os trens - o crescimento pentecostal no Brasil.

Já relativamente firmadas, aceitas pelo governo de Getúlio em todas as suas fases, as ADs crescem no Brasil em número avassalador. Depois, outros fatores foram responsáveis pelo contínuo crescimento dessa religião. 0 mais recente é o uso de mídia, típico da urbanidade.

Assim, o capitalismo e a técnica, com sua máquina de miserabilidade, assim como sua razão, produzem monstros, para citar a famosa obra de Goya. Esses monstros são produzidos em uma estética de morte, corrupção, invencibilidade e domínio, ou seja, a própria essência da monstruosidade. Ainda, o capitalismo moderno, ao se opor a certos valores, produz outros monstros como o fundamentalismo, o crescimento desenfreado das cidades e o aumento de violência em face da incompetência dos governos de controlá-la.

0 fiel, que se deixou seduzir pelos supostos confortos da cidade, os despreza e procura a afirmação de si mesmo na vontade de dominação do mundo, não mais vista como um meio para a realização dos valores mais altos, mas como fim em si mesmo, por meio da civilização da técnica, do industrialismo e do capitalismo. Ferreti $(1982$, p. 12) afirma, analisando as obras de Scheler, o seguinte:

Logo não há mais plenitude de vida, não mais o amor para o mundo e para a plenitude de suas qualidades, não mais a autocontemplação desinteressa como objetivo real do homem, mas cálculo utilitarista com fim em si mesmo, redução da natureza ao seu aspecto exatamente mensurável e seguramente dominável, fanatismo do trabalho e do lucro, avaliação somente das qualidades humanas de diligência, rapidez, capacidade de adaptação, que possuem uma utilidade aos fins lucrativos. 0 nascimento da ciência moderna e a concepção mecanicista da natureza não são as causas, mas sim os efeitos dessa nova atitude, que consagrou a natureza, privando-a de Deus, da alma, de todo valor e qualidade. 
Além da perda dos valores do espírito, a urbanidade causou um desgaste profundo nas relações humanas. Buber (2001) observou agudamente que, com o passar dos séculos, o mundo material se engrandeceu mais e mais, enquanto o mundo das relações pessoais pouco a pouco se restringiu. Um processo é a consequência do outro, visto que "o desenvolvimento da capacidade de experimentar e de utilizar cresce com a diminuição da capacidade do homem de criar uma relação dialógica" (BUBER, 2001, p. 45). Hoje, parece que a relação dialógica ficou menor e que cedeu lugar àquela do domínio entre homens e de subjugação entre esses e a natureza, subjugando a Deus.

Assim, nas ADs, em meio a esse mundo, funda-se sua comunidade na igreja, que é algo separado (santo) desse mundo e que oferece a plenitude, não da vida humana, mas de Deus, e segundo a crença da ADs, o que vem de Deus é melhor do que aquilo que o mundo oferece. Hoje, nas ADs, aceitam-se os produtos das tecnologias, mas ainda assim sua história foi fundada em gente que renegava as tecnologias e confortos do mundo.

Essa crise chamada Modernidade não passou despercebida aos religiosos, com suas crenças ferrenhas, cuja fé representa sua própria identidade. Assim, tal crise provocou reações dos religiosos contra a perda dos valores que se impunham. Estamos em época de efervescência religiosa (CAMPOS, 2002) e a religião reagiu contra essas mudanças trazidas pela Modernidade.

0 conservadorismo e a alienação ainda imperam na ideologia da ADs, não como algo maléfico e planejado, mas, sim, como uma última tentativa de ascetismo intramundano, de estar separado desse mundo. À medida que avança a crise de valores, mais se agarram aos antigos. Com o crescimento da mídia, da teologia e da prosperidade, certos líderes, em busca de poder e dinheiro, aproveitam essa mentalidade e a exploram. Esses líderes adoram aparecer em polêmicas justamente para isto: aparecer e passar a mensagem de defensores de antigas morais de modo aguerrido.

A manutenção de suas tradições não é fácil, muito menos a perda delas. A Modernidade, para o assembleiano, constitui-se em uma crise e a rígida manutenção dos seus valores é uma reação a isso, uma forma de proteger-se contra algo desconhecido, que é a Modernidade urbana.

Assim, procura-se uma forma de ser e agir no mundo, que, por vezes, pode ser retrógrada, mas consistente com uma identidade em formação. Sua identidade é ligada à sua convicção religiosa de santidade, a qual entende ser separada do mundo. Seu modo de ser e sua identidade constituem-se em santidade, a qual argumenta ser separação do mundo e dos desejos do mundo. É assim que se definem como separados dos desejos mundanos.

Seu discurso é uma eterna afirmação de socorro, que manifesta a impotência do homem ante esse quadro caótico, uma ideologia de salvação apocalíptica, segundo a qual o seu Deus logo vem the salvar desse mundo tenebroso. Assim se constitui o seu discurso religioso, alternando sempre entre o Deus que vem lhe socorrer e o diabo culpado das agruras do mundo. 
0 pentecostalismo, em geral, caracteriza-se como uma experiência religiosa ou como uma espiritualidade cristã mais do que uma particular interpretação do cristianismo. Não se trata, por exemplo, de uma teologia do Espírito Santo, mas de uma maneira de se relacionar com o divino, pois os assembleianos creem sentir a presença ativa do Espírito e percebem a manifestação do poder de Deus no indivíduo. Ou seja, Deus age, de fato, ou creem que Deus age diretamente por meio do Espírito em suas vidas, suas liturgias, sua vida econômica, sua saúde etc.

Acreditam que seu agir no mundo é guiado por providência e permissão do Espírito Santo, seu agir e sua sabedoria vêm então do divino. Usam para isso sua particular interpretação da Bíblia, já que não têm uma escola teológica a ser seguida. Há quase uma ausência de teologia que os guie, portanto, não é uma interpretação guiada por um pensamento ou escola humana, mas, sim, diretamente provinda de Deus. 0 protestante, em particular o pentecos$\mathrm{tal}^{4}$, não está imune às mudanças do mundo moderno nem ao que impacta sua identidade e sua memória. A modernidade impactou profundamente a igreja protestante e a identidade de seus fiéis (WESTHELE, 1992). 0 pentecostalismo ortodoxo também foi impactado. Hoje não é mais possivel saber quem é o pentecostal ou assembleiano com facilidade.

Vale lembrar que não há divisão entre profano e sagrado no sentido eliadiano, não há tempo e espaço dividido entre sagrado e profano, toda a sua vida é sagrada, toda a sua vida é para Deus. Seu agir no mundo é para Deus, e não veem outra escolha; se é de Deus é bom, portanto, não há juízo de valor em ferir certos direitos humanos. Simplesmente, o bem é a palavra sagrada, o que vai contra isso é o mal, não importa se a lei dos homens é respeitada.

\section{CONCLUSÃO}

0 agir do mundo do pentecostal clássico modelo é o temor a Deus. É uma sabedoria guia-

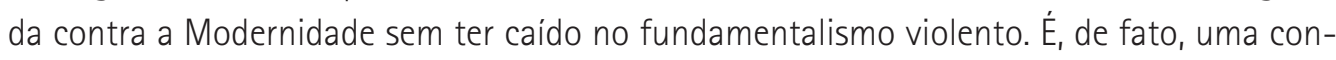
tracultura do mundo moderno, uma tentativa de negação desse mundo. Vivem não para a racionalidade do pensamento moderno, mas para uma espiritualidade particular e única.

Trata-se de uma sabedoria na contramão do que é considerado sabedoria na Modernidade - não mais acúmulo de conhecimento, mas acúmulo vazio e acrítico de informação provinda da instituição religiosa. Resolvem e posicionam-se no mundo com o que entendem ser o bem ou obediência à palavra de Deus. Sua ética se pauta nisto: o que é bom é fazer a vontade de Deus, mesmo que contrarie outros princípios éticos.

0 fato de obedecerem cegamente perfaz um certo fundamentalismo, que infelizmente é atravessado por interesses sempre escusos de exploração devido à falta de acesso à educa-

4 - Há quem diga que o neopentecostal não é protestante, referimo-nos aqui ao pentecostal ortodoxo (PAEGLE, 2008). 
ção do povo brasileiro, que o torna manipulável. Também os fiéis procuram obedecer, pois a religião é como uma fuga às suas agruras, nos mostra que mesmo no mundo moderno há uma outra forma de viver e se relacionar no mundo, por meio de uma antiga sabedoria judaica de viver sob o Temor do Senhor Deus. Lembro que para eles o Temor não é o terror, mas sim reverência e respeito a sua palavra, vivem por essa ética. Tal prática se manifesta, em tese, por viver em honestidade, não proferir palavras torpes, perdoar, evitar o pecado, e principalmente, e que difere de todas as outras religiões, na crença de que isso vem do Espírito e não de uma transformação ética de esforço próprio.

Nesse viés de acreditar que tudo o que faz ou que Ihe acontece é vontade (coisas boas) ou permissão (coisas ruins) divina, reconfigura sua identidade. A interpretação do divino pelos seres humanos nunca foi unânime, pode ser mudada e muda nas ADs. Muda constantemente conforme as mudanças socioculturais são absorvidas.

\title{
Memory and identities of the faithful of the assembly of god in relation to the urban and the field
}

\begin{abstract}
There are numerous common characteristics between the faithful of the assembly of God and the rural inheritance in Brazil. This article intends to make certain considerations about the influence of the Brazilian rural values in the constitution of the cultural matrix of the faithful of the Assembly of God. Moving from rural to urban, the message had to be unique and visual as well, it was a way of adapting to Modernity. In this maelstrom of intense and permanent transformations, the pentecostal religion enters the scene as a strategy of solution and signification of the passage, determining the limits within the great space without limits, reestablishing the ties of proximity, composing general meanings and resisting or negotiating with the new.
\end{abstract}

Keywords: Pentecostalism. Culture. History of religion. Sociology. Anthropology of religion.

\section{REFERÊNCIAS}

ALENCAR, G. F. de. Matriz pentecostal brasileira: Assembleia de Deus. 1911-2011. São Paulo: Novos Diálogos, 2013.

ALVES, R. O que é religião? São Paulo: Loyola, 1999.

BASTIDE, R. O sagrado selvagem e outros ensaios. São Paulo: Companhia das Letras, 2006. BECK, A.; FREEMAN, A. Terapia cognitiva dos transtornos de personalidade. Porto Alegre: Artes Médicas, 1993.

BODEN, M. A. The creative mind: myths and mechanisms. 2nd ed. London: Routledge, 2004. BOURDIEU, P. A economia das trocas simbólicas. São Paulo: Perspectiva, 1987. 
BRANDÃO, C. R. Crença e identidade: campo religioso e mudança cultural. In: SANCHIS, P. Catolicismo: unidade religiosa e pluralismo cultural. São Paulo: Edições Loyola, 1992. 39-40.

BRANDÃO, C. R. Os deuses do povo: um estudo sobre a religião popular. 2. ed. São Paulo: Brasiliense, 1986.

BUBER, M. Eu e tu. Tradução do alemão, introdução e notas Newton Aquiles Von Zuben. 10. ed. São Paulo: Centauro, 2001.

CABRAL, J. de P.; LOURENÇO, N. Em Terra de tufões: dinâmicas da etnicidade macaense. Macau: Instituto Cultural de Macau, 1993.

CAMPOS, B. Da Reforma protestante à pentecostalidade da igreja. São Leopoldo: Sinodal; Quito: Clai, 2002.

CASSIRER, E. Antropologia filosófica. 2. ed. São Paulo: Mestre Jou, 1977.

CERTEAU, M. A invenção do cotidiano. Petrópolis: Artes de Fazer, 2008. v. 1.

COSTA, S. Desprovincializando a sociologia: a contribuição pós-colonial. Revista Brasileira de Ciências Sociais, São Paulo, v. 21, n. 60, p. 117-134, fev. 2006. Disponivel em: http://www. scielo.br/scielo.php?script=sci_arttext\&pid=S010269092006000100007\&tng=en\&tnrm=iso. Acesso em: 9 mar. 2021.

DESROCHE, H. Sociologia da esperança. São Paulo: Paulinas, 1985.

DURKHEIM, É. As formas elementares da vida religiosa. São Paulo: Abril Cultural, 1996.

ELIADE, M. O sagrado e o profano: a essência das religiões. São Paulo: Martins Fontes, 2001.

FERRETI, G. Max Scheler, fenomenologia e antropologia personalística. São Paulo: Edusp, 1982.

HOBSBAWM, E. A Era das Revoluções: 1789-1848. Rio de Janeiro: Paz e Terra, 1991.

INSTITUTO BRASILEIRO DE GEOGRAFIA E ESTATÍSTICA (IBGE). Dados estatísticos sobre religião no Brasil, 2010. Disponível em: ftp://ftp.ibge.gov.br/Censos/Censo_Demografico_2010/Caracteristicas_Gerais_Religiao_Deficiencia/tab1_4.pdf. Acesso em: 16 set. 2020.

LEFEBVRE, H. La revolucion urbana. Madri: Alianza Editorial, 1972.

LEFEBVRE, H. Lógica formal, lógica dialética. Rio de Janeiro: Civilização Brasileira, 1983.

MARCUSE, H. A ideologia da sociedade industrial: o homem unidimensional. Tradução Giasone Rebuá. 4. ed. Rio de Janeiro: Zahar Editores, 1973.

MARIANO, R. Neopentecostais: sociologia do novo pentecostalismo no Brasil. São Paulo: Edições Loyola, 1999. 
MARTINS, J. de S. A aparição do demônio na fábrica: origens sociais do Eu dividido no subúrbio. São Paulo: Editora 34, 2008.

OTTO, R. O sagrado. Petrópolis: Vozes, 2007.

PAEGLE, E. G. de M. A posição política da Igreja Presbiteriana do Brasil (IPB) nos anos de chumbo (1964-1985). 2006. Dissertação (Mestrado em História) - Centro de Filosofia e Ciências Humanas, Universidade Federal de Santa Catarina, Florianópolis, 2006.

PAZ, O. Claude Lévi-Strauss ou o novo festim de Esopo. São Paulo: Perspectiva, 1977.

PESAVENTO, S. J. Além das fronteiras. In: MARTINS, M. H. (org.) Fronteiras culturais: BrasilUruguai-Argentina. São Paulo: Ateliê Editorial, 2002. p. 35-39.

PRADO JR., C. Formação do Brasil contemporâneo. 23. ed. São Paulo: Brasiliense, 2004.

RIBEIRO, D. O povo brasileiro: a formação e o sentido do Brasil. São Paulo: Companhia das Letras, 1996.

RICOEUR, P. A memória, a história, o esquecimento. Campinas: Unicamp, 2007.

RIVERA, P. B. Desencantamento do mundo e declínio dos compromissos religiosos: a transformação religiosa antes da pós-modernidade. Ciencias Sociales y Religión/Ciências Sociais e Religião, Porto Alegre, ano 4, n. 4, p. 87-104, out. 2002.

ROLIM. F. C. Pentecostais no Brasil: uma interpretação sócio-religiosa. Petrópolis: Vozes, 1985.

SANTOS C., M. A. 0. dos. Análise dos ministérios da igreja Assembleia de Deus e a sua lógica de funcionamento. 2008. Tese (Doutorado em Ciências da Religião) - Pontifícia Universidade Católica de São Paulo, São Paulo, 2008.

SANTOS, B. de S. Pela mão de Alice: o social e o político na transição pós-moderna. São Paulo: Cortez, 1997.

SANTOS, M. A natureza do espaço: espaço e tempo, razão e emoção. São Paulo: Hucitec, 1999.

WESTHELE, V. Teologia e Pós-modernidade. In: MARASCHIN, J. (org.). Teologia sob limite. São Paulo: Aste, 1992. p. 143-166.

WILLAIME J.-P. La précarité protestante: sociologie du protestantisme contemporaine. Paris: Labor et Fides, 1992. 